\title{
A Detailed Study on Identification and Categorization of Various Constraints Faced by Cashew Growers in Cuddalore District of Tamil Nadu Post the Impact of Thane Storm, India
}

\author{
M. Balarubini ${ }^{*}$, C. Karthikeyan ${ }^{2}$ and T.N. Sujeetha ${ }^{1}$ \\ ${ }^{1}$ Department of Agricultural Extension and Rural Sociology, TNAU, Tamil Nadu, India \\ ${ }^{2}$ Agricultural College and Research Institute, TNAU, Coimbatore, Tamil Nadu, India \\ *Corresponding author
}

\begin{tabular}{|c|c|}
\hline & A B S T R A C T \\
\hline & \multirow{6}{*}{$\begin{array}{l}\text { Climate change is widely accepted to be a prime cause for natural disasters. An } \\
\text { acute need to identify and understand the constraints faced by the disaster affected } \\
\text { farming community to provide them with appropriate solutions as a mean for } \\
\text { empowerment. The study was conducted in Panruti block of Cuddalore district } \\
\text { with sample size of } 194 \text { Thane affected cashew growers. The objective of the } \\
\text { paper is to analyse the constraints confronted by Thane affected cashew growers } \\
\text { on various dimensions. The respondents were interviewed personally by a well- } \\
\text { structured interview schedule. The findings clearly discuss about the five sub- } \\
\text { heads viz., production technology related constraints, psychological constraints, } \\
\text { social constraints, environmental constraints and personal constraints. Humongous } \\
\text { range of } 93.30 \text { per cent of respondents were found to not adopt erection of bore } \\
\text { wells as the main production technology related constraint. }\end{array}$} \\
\hline Keywords & \\
\hline & \\
\hline $\begin{array}{l}\text { Psychological, Social, } \\
\text { Environmental and } \\
\text { Personal. }\end{array}$ & \\
\hline Article Info & \\
\hline $\begin{array}{l}\text { Accepted: } \\
\text { 28 September } 2017 \\
\text { Available Online: } \\
10 \text { November } 2017\end{array}$ & \\
\hline
\end{tabular}

\section{Introduction}

Identification of problems and constraints faced by the disaster affected citizens is important to draw suggestions and frameworks for policies to overcome the problems identified. In the same lines, various studies in the past on problems/constraints faced by disaster affected farmers or people were surfed through and some of the relevant research findings pertaining to the present study is furnished. The constraints/ challenges faced in the Post Tsunami agriculture livelihood restoration include: (i) limitation of government reclamation plans, (ii) NGOs having their own ideologies/methodologies, (iii) donors working for a particular clientele group and (iv) high demands of the farming community (Chandramohan, 2006). The key lacunas still remaining in proper management of disaster is in redefining institutional based and, in that, ingraining adequate capacity is critically important. It is noted that in the affected coast, the preparedness has lost momentum beyond establishment of Tsunami Warning System for the Indian Ocean (Neupane, 2010). The Tamil Nadu Chief Minister also said that the fishermen will be eligible to get between 20 thousand to ' 1 lakh depending on the model of damaged vessels. 
But the Government is yet to announce any relief for crop damages (Women Federation, 2012). Cashew crop on about 29,000 Ha of land but not a single delivery has been made to the district. Hence, not a single farmer has been able to raise fresh crops. These farmers are having very poor yield because they are compelled to sell the raw cashews in low prices since they lack resources to invest in technologies for processing and packaging the nuts for enhancing product quality (Sachdeva, 2013).

The measures taken by the Government in the pre Thane cyclone are giving news about the cyclone, warnings and announcement of holidays. But, the respondents report that the Government did not assist in providing basic needs to the commons (Damodaran, 2015). The causes for adoption and non-adoption of recommended practices would help both the farmers and the extension functionaries to manipulate better planning and execution of mitigation efforts.

\section{Materials and Methods}

Considering the criteria viz., maximum area under cashew cultivation as well as maximum number of farmers affected by Thane storm, Panruti block of Cuddalore district was selected for the study. Considering the same criteria, the Block Development Office was also consulted to select the top three villages viz., Vegakollai, Kadampuliyar and Marangur which had maximum area under cashew cultivation as well as maximum number of farmers affected by Thane storm. Employing proportionate sampling method, 194 Thane affected cashew growers were selected randomly from the three selected villages. The primary data was collected during November, 2014. Percentage analysis was used to find out the frequency distribution of the constraints.

\section{Results and Discussion}

Constraints in adopting the relief measures by the Thane affected cashew growers

Thane being a natural disaster, the Government of Tamil Nadu has provided various mitigation and relief measures to counter the impact of the storm. It is of prime importance that the beneficiaries had to adopt these measures to reap the maximum benefits. During the research investigation the respondents had expressed various constraints in adopting the relief measures provided by various agencies.

The constraints encountered by the respondents in adoption of the recommended technologies for cashew cultivation PostThane are discussed under five heads. They are:

Production technology related Constraints

Psychological Constraints

Social Constraints

Environmental Constraints and

Personal Constraints

\section{Production technologies related constraints}

New and improved production technologies are being promoted by the Department of Horticulture envisaging the mitigation of the impact posed by Thane storm. The distribution of respondents based on their adoption status of various cashew production technologies is presented in the Table 1. Details furnished in the Table 1 are in the descending order based on the adoption status of the respective technologies by the respondents. The inferences drawn based on multiple interactions with the respondents in alignment to the constraints faced by them for non-adoption and reasons that influenced adoption behaviour is discussed in detail below: 


\section{Intercropping}

Intercropping is a known technology to enhance the income generating potential of a unit of land. Intercropping is a multiple cropping practices involving growing two or more crops in proximity. The most common goal of intercropping is to produce a greater yield on a given piece of land by making use of resources that would otherwise not be utilized by a single crop. Since the productivity and income generating capability of cashew was severely impacted by Thane storm, the farmers need to obtain maximum benefit out of their available land, water and other resources has enabled them to adopt intercropping to an extent of 100 per cent.

\section{Pesticide application}

Like any other commercially grown crop, cashew is also prone to pest and disease attack. The common pests quoted by the respondents are (i) Cashew Stem \& Root Borer (CSRB) - Plocaederus ferrugineus. (ii) Tea Mosquito Bug (TMB) - Helopeltis antonii. Since the pest incidence is ominous, application of pesticides has become imminent for the cashew growers to protect the crop and its yield. The respondents also expressed that the pest infestation has increased significantly Post-Thane due to lack of nutrition and resilience in the crop. Hence around 92 per cent of the respondents reported use of pesticides. About one-tenth $(8 \%)$ of the farmers who didn't take up application of pesticides expressed that they can't afford to go for chemical pest control and they go to others farm as labourers to make up the losses incurred due to pest incidence. The pesticides used by the growers for managing the above mentioned pests are given below;

CSRB: Coal Tar + Kerosene @ 1:2 ratio or swabbing 5 per cent Neem Oil coupled with soil application of Sevidol $4 \mathrm{G}$ at the rate of $75 \mathrm{gm}$ per tree to prevent adult beetles from laying eggs. Grow catch crops or host trees like Moringa and Silk Cotton to divert CSRB from cashew.

Management of TMB: Spraying of Profenophos 35 EC (1ml per Litre) and Carbendazim (1gm per Litre) during the fleshing period and if incidence is persistent take up another spray of Chlorpyriphos $2.5 \mathrm{ml}$ per Litre at one week interval was recommended.

\section{Treatment of seedling with bio-fertilizer}

Treatment of cashew seedlings with Biofertilizers like Azospirillum and Phospobacteria to enhance the plant capability to uptake available soil nitrogen and phosphorous respectively has an adoption level of 87.11 per cent. The key reason behind this large scale adoption is due to the availability and provision of these biofertilizers at free of cost by the State Department of Horticulture. The 12.89 per cent growers who come under non-adopter category revealed that these bio-fertilizers had not reached them at the time of planting. Yet, the growers expressed willingness to adopt the technology if it continues to be available at free of cost or subsidized cost.

\section{Appropriate spacing}

Spacing is an important criteria and fundamental principle in commercial production of any crop. Optimum space provided per plant/tree will enable the roots to grow with less competition for soil \& water resources and the shoots to grow luxuriously with less competition for sunlight \& air. Around 70.62 per cent of the growers had adopted appropriate spacing recommended by the State Department. The spacing recommended for VRI-3 are $5 \mathrm{mX} 4 \mathrm{~m}$ and $7 \mathrm{~m}$ $\mathrm{X} 7 \mathrm{~m}$. The higher extent of adoption was 
recorded due to the experience gained by the growers as well the rigorous education on proper spacing provided by the Department of Horticulture. About one-third of the growers had not adopted proper spacing due to the strong perceptions attached towards the spacing followed by them for the conventional variety over the past few decades. They also stated that, they had planted these trees long back while the recommendation related to spacing was not available for them and it is not a practically feasible solution for them to change the spacing with the trees fully grown and yielding cashew.

\section{Grafting (VRI-3)}

VRI-3, a variety identified and released by Regional Research Station (RRS), Vridhachalam, has proven potential of yielding three years after planting unlike the conventional varieties which has longer gestation period. Apart from this, VRI-3 is also known for its export potential due to the larger and bolder nut character. State Department has provided the VRI-3 grafts to the Thane storm affected growers at 100 per cent subsidy to hasten the disaster mitigation process. As a result of the aggressive campaign by the department of Horticulture, around 61.34 per cent of growers had adopted VRI-3 grafts whereas 38.66 per cent of growers had not taken up VRI-3 grafts owing to the following constraints: (i) farmers perceived on VRI-3 as a weaker tree as compared to that of conventional cashew tree. They also opined that, VRI-3 might not had last as long as conventional trees and has to be planted at least every 10 years, (ii) farmers expressed that conventional varieties can withstand weather vagaries and disaster better than VRI-3 and are comfortable with the gestation period of conventional varieties in the light of long term benefits and (iii) some of the farmers also expressed the nonavailability of the grafts as a major constraint even if they were willing to adopt.

\section{Pruning}

Pruning is a horticultural and silvicultural practice involving the selective removal of parts of a plant, such as branches, buds, or roots. Reasons to prune plants include deadwood removal, shaping (by controlling or directing growth), improving or maintaining health, reducing risk from falling branches, preparing nursery specimens for transplanting, and both harvesting and increasing the yield or quality of flowers and fruits. The practice entails targeted removal of diseased, damaged, dead, non-productive, structurally unsound, or otherwise unwanted tissue from crop and landscape plants.

Half of the growers $(52.58 \%)$ were found to be non-adopters of pruning practice due to the following constraints expressed by respondents viz., (i) lack of knowledge \& training with respect to aspects of pruning, (ii) scarcity of labourers to take up pruning operations and (iii) inability to afford for pruning operations due to poor remuneration effected by Thane.

\section{Bio-control Agents}

Bio control agents are an important component of Integrated Pest Management (IPM). Biological control is a bio effectormethod of controlling pests (including insects, mites, weeds and plant diseases) using other living organisms. It relies on predation, parasitism and other natural mechanisms, but typically also involves an active human management role. Bio control agents are ecofriendly and cost effective. 
Table.1 Production technology wise adoption level of cashew growers Post-Thane

\begin{tabular}{|c|l|c|c|c|c|}
\multicolumn{1}{|c|}{ Particulars } & \multicolumn{2}{c|}{ Adopted } & \multicolumn{2}{c|}{ Not Adopted } \\
\hline S.No. & \multicolumn{1}{|c|}{ Not } \\
\hline I & Technology related Constraints & No. & $\%$ & No. & \% \\
\hline 1 & Inter cropping & 194 & 100 & 0 & 0 \\
\hline 2 & Pesticide application & 179 & 92.27 & 15 & 7.73 \\
\hline 3 & Treatment of seedling with bio-fertilizer & 169 & 87.11 & 25 & 12.89 \\
\hline 4 & Appropriate spacing & 137 & 70.62 & 57 & 29.38 \\
\hline 5 & Grafting (VRI-3) & 119 & 61.34 & 75 & 38.66 \\
\hline 6 & Pruning & 92 & 47.42 & 102 & 52.58 \\
\hline 7 & Bio control agents & 55 & 28.35 & 139 & 71.65 \\
\hline 8 & Fungicide application & 45 & 23.2 & 149 & 76.8 \\
\hline 9 & Drip irrigation & 31 & 15.98 & 163 & 84.02 \\
\hline 10 & Fertigation & 31 & 15.98 & 163 & 84.02 \\
\hline 11 & Erection of bore wells & 13 & 6.70 & 181 & 93.30 \\
\hline
\end{tabular}

Table.2 Psychological constraints of cashew growers in adoption of relief measures

\begin{tabular}{|c|l|c|c|}
\hline \multicolumn{1}{|c|}{ Psychological Constraints } & Number & \% \\
\hline S.No. & \multicolumn{1}{|c|}{$(\mathrm{n}=194)$} \\
\hline 1 & Lack of interest in farming & 109 & 56.19 \\
\hline 2 & Fear about another natural disaster & 146 & 75.26 \\
\hline 3 & Lower self esteem & 77 & 39.69 \\
\hline 4 & Lack of motivation from development agencies & 129 & 66.49 \\
\hline 5 & Lack of conviction & 126 & 64.95 \\
\hline
\end{tabular}

Table.3 Social constraints faced by cashew growers in adoption of relief measures Post-Thane

\begin{tabular}{|c|l|c|c|}
\hline \multicolumn{1}{|c|}{ Social Constraints } & Number & \% \\
\hline S.No. & \multicolumn{1}{|c|}{$(\mathrm{n}=194)$} \\
\hline 1 & Lack of demand for labour & 77 & 39.69 \\
\hline 2 & Too many agencies give different recommendations & 55 & 28.35 \\
\hline 3 & Lack of technical guidance & 70 & 36.08 \\
\hline
\end{tabular}

Table.4 Environmental constraints faced by cashew growers in adoption of relief measures Post-Thane

\begin{tabular}{|c|l|c|c|}
\hline \multicolumn{1}{|c|}{ Environmental Constraints } & Number & \% \\
\hline S.No. & \multicolumn{1}{|c|}{} & $194)$ \\
\hline 1. & Unpredictable weather & 142 & 73.20 \\
\hline 2. & Unfavourable soil condition due to subsequent storm & 102 & 52.58 \\
\hline
\end{tabular}

Table.5 Personal constraints faced by cashew growers in the adoption of relief measures Post-Thane

\begin{tabular}{|c|l|c|c|}
\multicolumn{1}{|c|}{ Personal Constraints } & Number & \% \\
\hline S.No. & \multicolumn{1}{|c|}{$(\mathrm{n}=194)$} \\
\hline 1 & Diversion of relief fund received for some other purposes & 57 & 29.38 \\
\hline 2 & Non availability of relief material in required quantity & 159 & 81.96 \\
\hline 3 & Non availability of relief material in right time & 139 & 71.65 \\
\hline 4 & Inadequate credit for buying the inputs & 141 & 72.68 \\
\hline 5 & Feeling of non-necessity & 113 & 58.25 \\
\hline
\end{tabular}


State Department of Horticulture has provided biocontrol agents like Trichoderma and VAM (Vesicular Arbuscular Mycorrhizae) at 100 per cent subsidy to enable Thane affected growers to adopt IPM practices in order to control common pests and diseases. But, in spite of these efforts, only 28.35 per cent of the growers had adopted biocontrol agents and the constraints faced by a majority (71.65\%) for not adopting biocontrol were (i) lack of awareness and knowledge about biocontrol agents and their use, (ii) inadequate confidence or skeptical about the efficacy of biocontrol as against chemical control, (iii) non-availability of bio-control agents at the time of requirement and (iv) lack of awareness or idea on whom to contact or where to look up for biocontrol agents.

\section{Fungicide application}

The major disease often found in cashew crop is 'Die back or Pink Disease' caused by Corticium salmonicolor. The affected branches initially, show white patches on the bark and a film of silky thread mycelium develops on the branches during monsoon. Later, the fungus develop pinkish growth. In due course, the bark splits and peels off and the affected shoots starts drying up from the tip.

This disease can be controlled by pruning the affected branches below the spot of infection and destroying them, protecting the cut surface by application of Bordeaux paste and spraying of Bordeaux mixture 1 per cent twice.

Around 76.8 per cent of respondents report no use of chemical fungicides as they take up removal of the fungus infested barks from the affected trees as a control measure. The farmer also expressed this as a much more cost effective and efficient method to control the pink disease.

\section{Drip irrigation and fertigation}

Drip irrigation, also known as trickle irrigation, is an irrigation method that saves water and fertilizer by allowing water to drip slowly to the roots of plants, either onto the soil surface or directly onto the root zone, through a network of valves, pipes, tubing, and emitters. It is done through narrow tubes that deliver water directly to the base of the plant. State Department of Horticulture has provided drip irrigation to the Thane affected farmers in two modes i.e. (i) individual beneficiaries (50\% subsidy) and (ii) group or community beneficiaries $(75 \%$ subsidy). Among the respondents studied, a whopping 84.02 per cent were in non-adopters category with respect to drip irrigation and fertigation. The key reasons for non-adoption of drip irrigation and fertigation are (i) lack of water resource to implement drip irrigation technology in the farm/orchard, (ii) community engagement was not preferred by most of the respondents as the water source setup will be in a farmer location which may not be at the interest of others, (iii) subsidy provided for individual beneficiaries is at 50 per cent as against 75 per cent for group or community beneficiaries and (iv) respondents opined that drip as a technology was more favourable for big farmers rather than small farmers.

\section{Erection of bore wells}

Agricultural lands can pretend like gold mines when they are blessed with adequate ground water resource. To tap the invaluable ground water for the relief measure of Thane affected farmers, State Department of Horticulture has initiated provision of bore wells at 50 per cent subsidy for individuals and 75 per cent subsidy for group or community level beneficiaries. Humongous range of 93.3 per cent of respondents were found to not adopt bore wells and the same is being justified by 
them using the following reason and constraints; viz., (i) lack of ground water availability in the farms of the respondents, (ii) community engagement was not preferred by most of the respondents as the bore well would be set in some other farmers location and is not reliable, (iii) subsidy provided for individual beneficiaries was at 50 per cent as against 75 per cent for group or community beneficiaries and (iv) the criteria set by the Department of Horticulture, a minimum of 15 acres is required for an individual to avail the bore well subsidy which in straight benefits only large farmers and majority of the affected farmers in the study location belongs to small and marginal farmers $(72.68 \%)$.

\section{Psychological constraints}

Psychological constraints deal with the emotional quotient of the affected growers in coping up with the disaster and taking up relevant mitigation measures. The distribution of growers response on various psychological constraints as expressed by them is provided in the Table 2. The Table 2 indicates that 75.26 per cent of the Thane affected farmers expressed "fear about another natural disaster" followed by "lack of motivation from development agencies" (66.49\%), "lack of conviction" (64.95\%), "loss of interest in farming" $(56.19 \%)$ and 39.69 per cent expressed "lower self-esteem" as the reason for non-adoption of Post-Thane cashew cultivation practices. Wickrama (2006) also reported that 24.00 per cent of the Tsunami affected victims expressed both distress and family problems while 12.00 per cent expressed inadequate levels of self-efficacy for dealing with recovery from Tsunami related damages.

\section{Social constraints}

Social constraints are the constraints experienced by a Thane affected grower in adopting the relief measures provided by various agencies due to various elements or stakeholders of the social fabric. The distribution of respondents based on the social constraints expressed by them is provided as follows:

It could be observed from the Table 3 that 39.69 per cent of the Thane affected farmers felt "shortage of labour" followed by 36.08 per cent on "lack of technical guidance", 28.35 per cent on "too many agencies give different recommendations" as the reason for nonadoption of Post-Thane cashew cultivation practices. This is in line with the findings of Rodriguez et al., (2006) who reported that Tsunami affected Agricultural labourers have been left out of the proposed relief packages offered by the government.

\section{Environmental constraints}

Environment in the context of weather has a key role to play both constructive and destructive part in the play of Agriculture. The respondents have also expressed some of the environmental constraints faced by them primarily caused due to conditions caused by nature. The distribution of the respondents based on their responses pertaining to environmental constraints is provided in Table 4.

It is explicit from Table 4 that 73.20 per cent of the Thane affected farmers reported "unpredictable weather" as the main cause followed by 52.58 per cent revealed "unfavorable soil condition due to subsequent storm" as the major environmental constraints for non-adoption of Post-Thane cashew cultivation practices.

Ramachandran et al., (2006) also reported that Tsunami has caused significant damage to the ecosystem which will require long lasting effects. 


\section{Personal constraints}

Personal constraints in the context of this study speaks about the issues or impediments faced by the Thane affected grower which is not caused by any other external factor and is primarily due to self-decision or personal issues. The distribution of respondents based on the personal constraints faced by them in the adoption of Thane relief measures is as follows:

From the Table 5 it is clear that 81.96 per cent of the Thane affected farmers opined "non availability of relief material in required quantity" as the main constraint for nonadoption of Post-Thane cashew cultivation practices and nearly three-fourth of the respondents $(72.68 \%)$ perceived "inadequate credit for buying the inputs" and nonavailability of relief material in right time (71.65\%). Rodriguez et al., (2006) reported that "in some instances, NGOs duplicated efforts or provided assistance not suited to the locale or to the varying population sizes. Respondents have also expressed that there was discrimination based on community and alignments with respect to disaster aid allocation. Thane affected farmers have also stated that the credit provided by the funding agencies was not sufficient to buy the required inputs to take up rehabilitation activities in the affected farms (72.68\%) and around 58.25 per cent of the respondents had stated that they had a feel that these practices and relief measures were not felt necessary and there were other important things that should be taken on priority.

A majority of the Thane affected farmers expressed "fear about another natural disaster" as a key psychological constraint impeding them in taking up disaster mitigation and adopt improved practices for faster recovery. NGOs and other social organizations in cooperation with various mentoring agencies or psychological experts may take up mentoring sessions with affected growers for strengthening them mentally and empowering them to recover from the impact and fear of another disaster. Unpredictable weather is a critical environmental constraint expressed by the affected growers for nonadoption of disaster mitigation interventions provided by the Government agencies. Provision of near accurate weather related information continuously to the farming community through various channels of communication can enable the farmers' issue of unpredictability of weather. This can further be customized for a disaster micro zone and appropriate mitigation can be planned based on the predicted level of impact. A majority of the Thane affected cashew farmers opined that, "non-availability of relief material in required quantity" as the main constraint for non-adoption of various disaster mitigation interventions provided by various agencies. A permanent local level setup can be established by the Government for timely support, positioning and distribution of relief material in required quantities throughout a given year. This can again be linked to the Panchayat and the local disaster management committee for efficient calculation of required relief material, proactive procurement, strategic positioning and unbiased distribution to the disaster affected farming community.

\section{References}

Chandramohan. 2006. Post Tsunami Agriculture Livelihood Restoration - a District Level Co-ordination Effort. Paper presented at the Workshop on Disaster Preparedness in Agriculture, National Co-ordination Resource Centre (NCRC), Nagapattinam District, Tamil Nadu.

Damodaran, K. 2015. Government Action in the Pre and Post Thane Cyclone in Cuddalore District, Tamil Nadu. 
International Journal of Physical and Social Sciences, 5 (6): 646-651.

Neupane. B. R. 2010. Impact of the Dec 26, 2004 Tsunami on the Indian Coastal Groundwater: Remediation StrategyDid We Learn from the Disaster?, Paper presented In the Workshop on The Indian Ocean Tsunami: 5 Years Later, Assessing the Vulnerability and Resilience of Tsunami affected Coastal Regions, 1-3 March, 2010, Singapore.

Ramachandran, S., S. Anitha, V. Balamurugan, K. Dharanirajan, K. E. Vendhan, M. I. P. Divien, A. S. Vel, I. S. Hussain and A. Udayaraj. 2006. Ecological Impact of Tsunami on Nicobar Islands (Camorta, Katchal, Nancowry and Trinkat. Current
Science, 89 (1):195-200.

Rodriguez, Havidan, Wachtendorf Tricia, Kendra James and Trainor Joseph. 2006. A Snapshot of the 2004 Indian Ocean Tsunami: Societal Impacts and Consequences. Disaster Prevention and Management, 15 (1): 163-177.

Sachdeva, Shibani. 2013. Support 200 Cashew Farmers Impacting 1000 Lives in Tamil Nadu, Planet Finance Report, India.

Wickrama, K. A. S. 2006. Report on the Tsunami Damages and Recovery of WDF Families in the Hambantota District of Srilanka.

Women Federation. 2012. Rapid Assessment: Thane Cyclone Affected Villages in Cuddalore, Cuddalore.

\section{How to cite this article:}

Balarubini, M., C. Karthikeyan and Sujeetha, T. N. 2017. A Detailed Study on Identification and Categorization of Various Constraints Faced by Cashew Growers in Cuddalore District of Tamil Nadu Post the Impact of Thane Storm, India. Int.J.Curr.Microbiol.App.Sci. 6(11): 39924000. doi: https://doi.org/10.20546/ijcmas.2017.611.468 